\title{
Methodological Approach to Studying Unintended Consequences of Digitalization in Education
}

\section{Daria Goloukhova and Elena Kuzmina}

Moscow State Institute of International Relations, Moscow, Russian Federation

\section{Abstract}

The article describes sociological research methodology referring to the problems of digitalization in education. The authors' concept of digitalization is defined according to the specific aims of the study, emphasizing the peculiarities of the educational sphere. Digitalization in education can be considered as an introduction and active use of digital technologies at different stages of the educational process. The study has determined that the introduction of digital technologies in education leads to the unintended consequences which can have unanticipated effects on educational institutions and their actors. The unintended consequences are conceptualized using

Corresponding Author:

Daria Goloukhova

d.v.goloukhova@inno.mgimo.ru

Published: 21 January 2021

Publishing services provided by Knowledge E

(c) Daria Goloukhova and Elena Kuzmina. This article is

distributed under the terms of the Creative Commons.

Attribution License, which permits unrestricted use and redistribution provided that the original author and source are credited.

Selection and Peer-review under the responsibility of the XXIII International Conference Conference Committee.
R. Merton's theoretical perspective and are defined as unexpected, unforeseen results caused by a purposive action. They could be divided into three subgroups: 1) unexpected benefit, 2) unexpected drawback, 3) perverse result. To study the unintended consequences the authors designed a methodological approach which focuses on macro and micro factors which determine attitudes to digitalization on the part of various participants of the educational process. The complex structure of the empirical object is determined by the hypothesis, that the unintended consequences of digitalization vary for different social groups involved in the process of education and highly depend on the context. The educational process is described as a complex system with two major components and structured in accordance with specific spheres in which introduction of digital technologies is possible. In conclusion, authors put forward a hypothesis that the suggested methodological approach will contribute to relating the unintended consequences of digitalization to their sources, also identified by R. Merton: ignorance or incomplete analysis; errors in analysis of the problem or following outdated habits; immediate interests overriding the long-term ones; following basic values which require / prohibit certain actions; self-defeating prophecy.

Keywords: digitalization, socio-educational sphere, education, unintended consequences, attitudes to digitalization

\section{Introduction}

Social change leads to the transformations of all social institutions, including the institution of education - the paradigm in which it exists and functions, the rules established for teachers and students, the methodology of the educational process. Over the past 
decades, educational institutions have undergone constant changes at the global level [11]. Scientists distinguish three major transformations [3] that have occurred in the educational sphere during this time. Firstly, it is the transition to mass education, which began in the second part of 20th century with a large increase in the number of students worldwide. The second big transformation is the standardization that took place in Europe as a result of the Bologna process and the Lisbon strategy. This standardization, introduced in the process of certification and accreditation, is aimed at the unification of European diplomas and, in a broader sense, the unification of educational standards worldwide. Finally, the third wave of changes is associated with the active introduction and use of digital technologies and with the development of new types of training based on the active use of these technologies. The phenomenon of digitalization and its impact on society, the transition to the new round of not only technological, but also social development, has not been deeply studied. In addition to the declared and calculated economic efficiency from the introduction of digital technologies, digitalization entails a number of unintended consequences, both functional and dysfunctional in nature, and even digital riks [7]. Moreover, the effect of the same set of innovations can affect various groups in different ways. For example, the unification of the school curriculum for preparing for the Unified State Exam (partially checked by computer) negatively affects the creative potential of both teachers who are forced to change their unique teaching methods in favor of stuffing students for the standard test tasks, and students who do not learn to think logically and critically. At the same time, digitalization itself led to the emergence of a new educational institution - online schools and universities, whose teachers, on the contrary, develop unique courses and use innovative methods to attract more students.

The institution of education is, on the one hand, quite conservative, because it is designed to preserve and transmit accumulated knowledge, values, and wellestablished practices. But on the other hand, it's very innovative, because it is necessary to respond quickly to socio-economic changes in order to supply qualified personnel to the labor market. Therefore, the study of the effects of digitalization on the educational system seems relevant and necessary. Thus, the aim of our work is to develop and validate the methodology for studying the unintended consequences of digitalization in education. 


\section{Methodology and Methods}

Digitalization is widely regarded as the process of converting data from analogue to digital form [6]. There are different approaches to the concept of education digitalization which depend on the aims of the research (research for business, research in higher education, research by officials implementing educational technologies). Summarizing the existing approaches to digitalization, we could define digitalization in education as introduction and active use of digital technologies at different stages of the educational process. Digitalization is now becoming a part of the state program in Russia, it is on the agenda which is broadcasted by top public officials [1]. The project "Digital educational environment" is included in the national project "Education", which is planned to be implemented until 2024 [10]. The main goal of the federal project "Digital educational environment" is to create a modern and safe digital educational environment by 2024 ensuring high quality and accessibility of education of all types and levels.

As for unintended consequences, we can rely on the definitions introduced by R.Merton in the article "The unanticipated consequences of purposive social action" [9]: unintended consequences are unexpected, unforeseen results caused by a purposive action. They could be divided into three subgroups: 1) unexpected benefit; 2 ) unexpected drawback; 3) perverse result.

Suggested methodology of studying the unintended consequences of digitalization in education is based on the premise, that these consequences vary for different social groups involved in the process of education and highly depend on the context. Thus, the requirement for university staff to design and develop online courses might benefit students who get easy access to additional learning materials, but, if made obligatory, might have a negative effect on teachers who are not well familiar with the technology in general and online learning platforms in particular. Therefore, within the empirical object of the study we can identify the following groups, depending on their position in the educational process (table 1).

The structure of the empirical object is determined by the subject field of the study which can be defined as the consequences of the digital technologies introduction in the subsystems of the educational process. These consequences can be observed both on marco and micro level. The educational process is a complex system, but regarding the aim of our research we can identify two major components: 1) teachinglearning process as the fundamental subsystem; 2) control and management as the supplementary subsystem whose main aim is to ensure that the teaching-learning process goes smoothly and is in line with the governmental requirements. 
TABLE 1: Model of the empirical object.

\begin{tabular}{l|c|c|c|c|}
\hline $\begin{array}{l}\text { Preschool } \\
\text { kindergarten } \\
\text { teachers }\end{array}$ & $\begin{array}{c}\text { Secondary } \\
\text { education }\end{array}$ & $\begin{array}{c}\text { Specialized secondary education } \\
\text { school teachers }\end{array}$ & $\begin{array}{c}\text { Higher } \\
\text { education }\end{array}$ & $\begin{array}{c}\text { Additional } \\
\text { education }\end{array}$ \\
$\begin{array}{l}\text { kindergarten } \\
\text { children }\end{array}$ & pupils & teachers & \\
\hline parents & students \\
\hline $\begin{array}{l}\text { administrative } \\
\text { staff } \\
\text { management }\end{array}$ & & & \\
\hline $\begin{array}{l}\text { technicians } \\
\text { technology } \\
\text { developers }\end{array}$ & & & & \\
\hline
\end{tabular}

Digitalization in the teaching-learning process mainly affects teachers, students and parents (regarding primary and secondary education) as it suggests introducing digital technologies into its major elements: 1) The scope of digitalization in teaching can vary from teachers using Powerpoint presentations to deliver new material to designing online courses; 2) Digitalization in learning includes students using digital textbooks, doing tasks online, watching educational videos and using other additional digital materials; 3) Digitalization facilitates communication between university staff and students as well as between university staff and parents and makes it easier for the learners to get detailed feedback on their performance.

Digitalization in teaching and learning helps teachers and students to develop their creativity, it can make lessons more dynamic, practice-oriented and boost interest in the subject [3]. A wider range of teaching techniques can be applied to make studies more effective. Meanwile, the unintended consequences in the form of unexpected drawbacks and perverse results include health concerns [12], distractions resulting from the decreased motivating influence of the teacher, unification of teaching methods and techniques, limited access to digital technology resulting in academic failure. Possible structural consequences can also involve lack of qualified teachers able to use digital tools in the classroom resulting in understaffing of educational institutions, increasing financial costs and regulatory concerns [3].

Thus, studying the effects of digitalization in teaching and learning on teachers, students and their parents would involve the research of both attitudes to digitalization and specific practices. In this regard, we can set a number of research questions:

Which factors determine (un)acceptance of digital technologies and positive/negative attitude to it? 
Which factors determine introduction of digital technologies in the classroom?

Which particular technologies do teachers and students use? Which factors determine their choice?

How do teachers/students/parents access the effectiveness of using digital technologies in the classroom? Which drawbacks they see?

Which problems do teachers face when they decide to introduce digital teaching techniques?

Digitalization of control and management in education can also be studied at the following levels:

formal control of students: an electronic grade book facilitates control of attendance, progress and grades, student schedules and other records;

digital forms of knowledge control vary from holding digital tests and exams (including the Unified State Exam) to checking students' papers for plagiarism;

digital control of the educational institution can be both formal (digital reporting) and informal (includes various independent ratings and reviews);

digital administration involves multiple solutions, such as electronic schedule, CRM systems, corporate e-mails, etc.;

digitization of the educational infrastructure.

Digitalization of control and management aims at making educational process more efficient and more transparent, however, it can also lead to the unintended consequences both at micro and macro level. At micro level two major problems can be identified. Firstly, it is the worsening quality of education as the result of unified methods of knowledge control. Thus, in order to prepare for the Unified State Exam student learns to solve typical tasks instead of developing critical thinking and creativity. Secondly, intensified control over students can lead to increasing psychological pressure and general aversion to schooling. At macro level the unintended consequences can be analyzed through the concept of accessibility. There is an evident contradiction between the national requirements to introduce digital technologies in educational institutions and accessibility of these technologies both in terms of infrastructure and qualified personnel. The problem must be the most pronounced at the regional level.

The following research questions can be brought forward:

Which factors determine positive/negative attitude to digital control over students?

How do attitudes to digital control differ among various social groups?

Do digital technologies make administration more efficient? 
Which management problems do educational institutions face when they introduce digital technologies?

Answering research questions would require using a set of research methods. An online opinion poll would be used to assess the attitudes to digitalization among students. Students are the most numerous and easily accessible group, the vast majority of them is active internet users, which significantly lowers the risk of receiving unrepresentative data.

In-depth interviews would be used to collect data from the management and technology developers. The Delphi method would be used to assess the macro consequences of digitalization and design possible solution to the problems which arise with the introduction of digital technologies into educational management.

Online focus groups will be used to study attitudes and practices of teachers and administrative staff. In this way it will be possible to stimulate an active discussion and produce insights into possible consequences of digitalization which have not been yet conceptualized in literature.

Finally, parenting communities in social nets will be studied using netnography, an online research method based on participant observation.

\section{Results and Discussion}

The problems of digitalization in education are widely discussed by the scientific community. However, the main emphasis is made either on quantitative indicators of digital technologies use [2], or on the introduction of digital technologies in higher education $[3 ; 4 ; 8]$ or on the digitalization of educational technologies for the business sector [5]. The novelty of the authors' research of digitalization in education comprises precisely in studying the consequences of the digitalization for the key participants of the educational process.

The research which would be subsequently conducted according to the methodology developed by the authors will contribute to conceptualization of the unintended consequences that occur during the educational institutions digitalization. The integral character of the suggested methodology will make it possible to relate the unintended consequences of digitalization to their causes, which can be classified in accordance with the theoretical terms of R. Merton [9], who identified five possible sources of unintended consequences: 
1. Ignorance or making it impossible to anticipate everything, every detail, thereby leading to incomplete analysis.

2. Errors in analysis of the problem or following habits that used to work in the past but may not apply to the current situation.

3. Immediate interests which override long-term interests.

4. Basic values which may require or prohibit certain actions even if the long-term result might be unfavorable.

5. Self-defeating prophecy, or, the fear of some consequence which drives people to find solutions before the problem occurs, thus the non-occurrence of the problem is not anticipated.

The digitalization process has been launched in order to increase the availability of education, the effectiveness of teaching and learning, the improvement of educational methods, the transparency of the educational process and the assessment of students' knowledge. However, due to a number of factors [9] that appear in the process of implementation and use of digital educational technologies, unintended consequences which can adversely affect both the digitalization process and the education system as a whole have occurred. To identify these unintended consequences and underlying causes, we need to examine the attitude to the introduction of digital educational technologies among different participants of the educational process.

\section{Conclusions}

The main focus of the suggested research is on the attitude to digitalization on the part of the various participants of the educational process which is described as a complex system with two major components. Each subsystem is structured in accordance with specific spheres where introduction of digital technologies is possible. The posed research questions are aimed at describing factors which determine both attitudes to digitalization and introduction of specific practices by various actors on macro and micro level. It is suggested, that the developed approach to studying the unintended consequences of the digitalization in education can further help to relate the unforeseen effects of digitalization to the causes conceptualized in Merton's terms. 


\section{Acknowledgments}

The research is funded by the Presidential Grant for the state support of leading scientific schools of the Russian Federation (competition of 2020), application NSh-2615.2020.6.

\section{References}

[1] Council of Experts under the Authority of the Russian Government 2020. The President Called for Comprehensive Digitalization. https://open.gov.ru/events/ 5517496. [Accessed February 20 2020].

[2] Gaslikova, I. R. and Kovaleva, G. G. (2005). Indicators of the Use of Information Technology in Education. Voprosy obrazovaniia 3: 302-330.

[3] Ghozlane, S., Deville, A. and Dumez, H. (2016). Enseignement supérieur: mythes et réalités de la revolution digitale. Gérer \& Comprendre 126: 28-38.

[4] Institut Montaigne. (2017). Enseignement supérieur et numérique: connectez-vous! Report 06/2017. Institut Montaigne, Paris, France.

[5] Kadyrbaeva, A. (2019). Digitalization in Staff Training. In: Proceedings of the Conference Digital Competencies: Assessment and Development. HSE, SaintPetersburg, Russia.

[6] Khalin, V. G. and Chernova, G. V. (2018). Digitalization and its Impact on the Russian Economy and Society: Advantages, Challenges, Threats and Risks. Administrative Consulting, 10: 46-63.

[7] Kravchenko, S. A. (2019). Digital Risks, Metamorphoses and Centrifugal Trends in Youth. Sotsiologicheskie iss/edovaniia 10: 48-57.

[8] Mavlyutova, G. A. (2018). Digitalization in a Modern Higher Education Institution. Ekonomicheskaia bezopasnost' i kachestvo 3 (32): 5-7.

[9] Merton, R. (1936). The Unanticipated Consequences of Purposive Social Action. American Sociological Review 1(6): 894-904.

[10] Ministry of Education of the Russian Federation 2020. https://edu.gov.ru/nationalproject. [Accessed February 20 2020]

[11] Noskova, A. V. and Proskurina, A. S. (2019). Intra-University Ratings of Teachers: The Empirical Case of MGIMO. Sotsiologicheskie issledovaniia 10: 69-75.

[12] Wutz, I. (2020). The Transformative Power of Digitalization in Schools: Where to Draw The Line? COFACE Families Europe: Policy Brief 11/2018. COFACE Families Europe, Brussels, Belgium. 